\title{
The influence of project-based learning strategies on the metacognitive skills, concept understanding and retention of senior high school students
}

\author{
Dominggus Rumahlatu, Kristin Sangur
}

Biology Education Study Program, Pattimura University, Indonesia

\section{Article Info \\ Article history: \\ Received Sep 15, 2018 \\ Revised Oct 29, 2018 \\ Accepted Nov 12, 2018}

\section{Keywords:}

Concept understanding

Metacognitive

Project based learning strategies

Retention

\begin{abstract}
Biology learning in the 21 st century leads to the empowerment of metacognitive skills. Increased metacognitive skills can support concept understanding and maximize the students' retention of concepts. This research aimed at investigating the effect of project-based learning strategy on metacognitive skills, concept understanding and retention of class X students of Senior High School 1 Kairatu, West Seram District, Maluku. This research is a quasi-experimental research using pre test-post test nonequivalent control group design. The samples of this research were all students of class $X_{1}$ of Senior High School 1 Kairatu. The data obtained in this research were the learning results of metacognitive skills, concept understanding, and retention of the students. The data were analyzed by using analysis of covariance (ANCOVA). The research results showed that the implementation of project-based learning strategy had a significant effect on students' metacognitive skills, concept understanding, and retention. Furthermore, the results of post hoc LSD test showed some differences in the notation between the project-based learning strategy and the conventional learning strategy. These results indicated that the learning stages of projectbased learning strategy could empower the students' metacognitive skills, concept understanding, and retention.
\end{abstract}

Copyright () 2019 Institute of Advanced Engineering and Science. All rights reserved.

\section{Corresponding Author:}

Dominggus Rumahlatu,

Biology Education Study Program,

Pattimura University,

Ir. M. Putuhena Street, Kampus Poka-Ambon 97233, Indonesia.

Email: dominggus_amq@yahoo.co.id

\section{INTRODUCTION}

Biology learning in the 21st century is directed to student-centered learning. The orientation of student centered learning is to emphasize the student learning on inquiry or investigation. Windschitl [1] explains that the main focus of the students' 21 st century learning is to solve complex problems, and the students' learning activities are focused on collecting relevant information, collecting data, testing the model, learning new concepts required to understand problems.

Biology learning process should also improve the skills of the 21 st century, because the 21 st century skills include logical thinking skill, metacognitive skill, and entrepreneurship thinking [2-4]. Metacognitive skill, one of the 21st century skills, can be interpreted as thinking about thinking. Tan [5] states that in the 21 st century learning, students need metacognition as key to enhancing their thinking skills. Similarly, Greenstein [6] and Harun [7] explain that the demands of 21st century learning are that students know not only about the content of learning but alsoabout how students learn and develop their metacognitive thinking skills. Yusnaeni and Corebima [8] adds that the students who have good metacognitive skills can become independent learners during the learning process. Independent learners means being able to determine how to 
learn, when to learn, and to manage their own learning as well as to evaluate the results of the learning process. The development of the students' metacognitive skills can help students understand the learning process, thus, enhancing the students' concept gaining and retention. Listiana et al [9] found that independent learners are responsible for the improvement of their learning, and they can determine the best instructional strategies to accomplish the tasks set by the teachers.

Project-based learning strategy is a learning strategy which is oriented on investigation and requires the students' total activeness to complete a project. During the learning process, the teacher serves as a facilitator and motivator to direct the students, so that the students can work on the project well and finish it on time. He final stage of project-based learning is producing a scientific product in the form of scientific papers, reports, posters, leaflets, or media that can be displayed to the other groups. Meanwhile, Thomas [10] describes that project-based learning has five criteria, namely qustion-centered, constructivist-investigation, independence, realism, and focusing on the problems that can lead the students to experience the investigation process of the concepts and principles of the learning material. In line with the Thomas' opinion, Bell [11] explains that in the project-based learning, students construct new knowledge and build on the base knowledge, so that the students can master a lot of information when they learn by doing. Ilter [12] explains that the project-based learning is learning with a scientific approach, enhancing metacognitive strategies, producing a product which is suitable with the topic being discussed.

There have been many researches onthe empowerment of metacognitive skills. Yusnaeni and Corebima [8] report that the integration of the SSCS + MS learning model has the potential to increase students' metacognitive skills. Listiana et al [9] report that metacognitive skills have a significant correlation with Biology cognitive learning results. Sele et al [13] in his research using conventional learning, TPS, RT and the integration of TPS and RT, reported that the metacognitive skills of senior high school students in Malang taught by using conventional learning strategy were very low compared to those taught by using TPS, RT and the integration of TPS+RT learning strategies. Furthermore, it was found that the lower the metacognitive skills were, the lower the students' critical thinking skills were.

If the students' metacognitive skills have a positive effect on students' concept gaining, the students' concept gaining also has an effect on students' retention. The research on the correlation between cognitive ability and retention was also reported by Setiawati and Corebima [14] that there was a significant correlation between the students' average-ability and the students' retention. Wicaksono and Corebima [15] report that metacognitive skills have a positive correlation with the students' retention. Thus, it can be concluded that to improve the students' retention, their metacognitive skills should be initially empowered. Some research findings have shown that empowering metacognitive skills has an effect on the students' cognitive abilities and retention. However, there has not been any research investigating the implementation of project-based learning strategy to empower students' metacognitive skills, retention, and concept gaining on the concepts of biodiversity. Therefore, the purpose of this research was to examine the effect of project-based learning strategy on metacognitive skills, concept understanding, and retention of class X students of Senior High School 1 Kairatu.

\section{RESEARCH METHOD}

\subsection{Research Design}

This research is a quasi-experimental research which is conducted to compare the effectiveness of conventional learning strategy and project-based learning strategy in improving the students' metacognitive skills, concept understanding, and retention. Confounding variables such as gender, initial students abilities, and students skills are controlled by placing heterogeneous students into study groups. The design of this research was pre test-post test nonequivalent control group design Table 1.

Table 1. Research Design

\begin{tabular}{|c|c|c|c|}
\hline Group & Pretest & Learning Strategy & Posttest \\
\hline Conventional Learning Strategy (Control) & $\mathrm{O}_{1}$ & $\mathrm{X}_{1}$ & $\mathrm{O}_{2}$ \\
\hline Project Based Learning Strategy & $\mathrm{O}_{3}$ & $\mathrm{X}_{2}$ & $\mathrm{O}_{4}$ \\
\hline \multicolumn{4}{|l|}{ Description: } \\
\hline $\mathrm{O}_{1}$ and $\mathrm{O}_{3}:$ Pretest & & & \\
\hline $\mathrm{O}_{2}$ and $\mathrm{O}_{4}:$ Posttest & & & \\
\hline $\mathrm{X}_{1} \quad$ : Conventional learning strategy & & & \\
\hline : Project-based learning strategy & & & \\
\hline
\end{tabular}




\subsection{Research Sample}

This research was conducted in Senior High School 1 Kairatu West Seram District. The sample of this research was 40 students of class X Senior high school 1 Kairatu in the first semester of the 2017/2018 academic year.

\subsection{Instruments}

The instruments used in this research were int he form of an essay test using metacognitive rubric and concept understanding rubric and retention developed by Corebima [16]. The essay test was given at the begining (pretest) and at the end (posttest) of the research. Before used, the interusments had been validated by experts.

\subsection{Experimental Process}

Two classes were used as the research samples, namely class $\mathrm{X}_{1}$ and $\mathrm{X}_{2}$. Class $\mathrm{X}_{1}$ was taught by using conventional learning strategy, while class $\mathrm{X}_{2}$ was taught by using project based learning strategy. The learning material used in this research was about Biodiversity. The conventional learning in the control class was carried out by the teacher without any intervention from the researcher. The experimental class was taught by using project based learning by the researcher. A pretest and posttest were administered before and after the research was conducted.

\subsection{Data Analysis}

The data were analyzed by using ANCOVA test followed by post hoc LSD test (Least Significant Different test). The pre test, metacognitive skills, concept understanding, and post test were used as the covariates. Before the ANCOVA test was performed, the normality of the data were initially tested using Kolmogorov-Smirnov test, and the homogeneity of the data was tested using Levene's test.

\section{RESULTS AND ANALYSIS}

The results of the normality test of the students' metacognitive skills, concept understanding, and retention using Kolmogorov-Smirnov test showed that the data were normally distributed $(p>0.05)$. the results of the homogeneity test of the students' metacognitive skills, concept understanding, and retention using Levene test of Equality of Error Variances indicated that the data came from homogeneous population $(\mathrm{p}>0.05)$. Therefore, the data had normal distribution and were homogeneous. Thus, the covariance analysis of the students' metacognitive skills, concept understanding, and retention could be performed. The results of ANCOVA test on the students' metacognitive skills, concept understanding, and retention are presented in Table 2; Table 4; and Table 6. While the LSD post hoc test of each variable is presented in Table 3; Table 5 and Table 7.

Table 2. The Results of ANCOVA on the Metacognitive Skills of Senior High School 1 Kairatu

\begin{tabular}{cccccc}
\hline Source & Type III Sum of Squares & Df & Mean Square & F & Sig. \\
\hline Corrected Model & $1273.556^{\mathrm{A}}$ & 2 & 636778 & 20242 & .000 \\
Intercept & 14566.466 & 1 & 14566.466 & 463046 & .000 \\
Pre-test & 28661 & 1 & 28661 & .911 & .346 \\
Strategy & 1079.512 & 1 & 1079.512 & 34316 & .000 \\
Error & 1163.944 & 37 & 31458 & & \\
Total & 306503.906 & 40 & & & \\
Corrected Total & 2437.500 & 39 & & & \\
\hline
\end{tabular}

The results of ANCOVA test Table 2 show that the learning strategy variable has an effect on the metacognitive skills of students of Senior High School 1 Kairatu $(\mathrm{p}<0.05)$. Once it was found that learning strategy had an effect on the students' metacognitive skills, the LSD test was then performed. The post hoc LSD test was to determine differences in the metacognitive skills between the students taught by using project based learning strategy and those taught by using conventional learning, as shown in Table 3 .

Table 3. The Results of Post Hoc LSD Test on the Metacognitive Skills of the Students of Senior High School 1 Kairatu

\begin{tabular}{ccccc}
\hline Class & X Metacognitive & Y Metacognitive & Difference & LSD Notation \\
\hline Control_Conventional Strategy & 6.59 & 27 & 20.41 & $\mathrm{a}$ \\
Experiment_Project-Based Learning Strategy & 9.57 & 32.3 & 22.73 & $\mathrm{~b}$ \\
\hline
\end{tabular}

J. Edu. \& Learn. Vol. 13, No. 1, February 2019 : $104-110$ 
Project-based learning strategy has better potential in improving students' metacognitive skills compared with the conventional learning strategy with the score difference between the pretest and posttest scores as much as 22.73 Table 3. The results of this research show that the implementation of project-based learning strategy can train the students to be independent learners in planning the project, responsible for the implementation of the project, and reporting the results / products obtained, so that their metacognitive skills are empowered. When the students are engaging in the project-based strategy, their metacognitive skills, whose characteristics include independence, planning, responsibility and evaluation, are raised and honed to become more quality. Through the project-based learning strategy, the students' metacognitive skills are honed and developed. This is because the project-based learning strategy emphasizes on the students' activities and on their cognitive constructivist. Tan [5] revealed that the project-based learning directed the students to build their knowledge. Suwono [17] explains that the project-based learning is a student-centered learning, using a variety of ways, and is an active learning approach in education. Thomas [10] and Hellstrom et al [18] explain that one characteristic of the activity in project-based learning is that the projects involve the students in a constructive investigation. Palennari [19] explains that through metacognition, students become an independent learners, students can organize and plan the learning process. In line with this, Yusnaeni and Corebima [8] and Corebima [16] reveal that independent learners are responsible for their own learning progress and their own efforts, able to monitor and evaluate their learning activities before and after the learning activity.

During the conventional learning strategy, the students were assigned to answer the student worksheet. This made the students not learn to be independent and responsible for the planning process and the resulting products. Therefore, the metacognitive skills of students in conventional learning class were lower than those in the project-based learning strategy class. The research by Listiana et al [20] reported that the conventional learning activity, such as answering student worksheets and discussions,made the students passively receive information from teachers. In addition, such activity did not empower the students' skills. Project-based learning strategy can be used to enhance the students' concept understanding Table 4. The research by Suparti [21] proves that the project-based learning can improve the students' learning results, so that the students' research skill can be achieved because project-based learning facilitates the students to identify problems.

Table 4. The Results of ANCOVA Test on the Concept Understanding at Senior High School 1 Kairatu

\begin{tabular}{cccccc}
\hline Source & Type III Sum of Squares & df & Mean Square & F & Sig. \\
\hline Corrected Model & $300.833^{\mathrm{a}}$ & 2 & 150.416 & 38.901 & .000 \\
Intercept & 1480.507 & 1 & 1480.507 & 382.888 & .000 \\
Pre-meta & 4.176 & 1 & 4.176 & 1.080 & .305 \\
Strategy & 201.294 & 1 & 201.294 & 52.059 & .000 \\
Error & 143.067 & 37 & 3.867 & & \\
Total & 36564.000 & 40 & & & \\
Corrected Total & 443.900 & 39 & & & \\
\hline
\end{tabular}

The results of ANCOVA test Table 4 show that the learning strategy variable makes a difference toward the concept understanding of the students of senior high school 1 Kairatu $(\mathrm{p}<0.05)$. This shows that learning strategy has a significant effect on the students' concept understanding. Having been found that learning strategy has a significant effect on the students' concept understanding, the LSD test is performed. On the other hand, the post hoc LSD test Table 5 was performed to determine the significant difference in the students' concept understanding between the project based learning strategy and conventional learning strategy. The results show that project-based learning strategy has a greater potential in improving the students' concept understanding than does the conventional learning strategy, with a score difference between pretest and posttest as much as 4.19. The research by Koparan and Guven [22] reports that projectbased learning method is more effective than conventional learning method, moreover, project-based learning can improve the students' collaboration by using student-centered principle which is more effective and efficient.project-based learning method is more effective than conventional learning method, moreover, project-based learning can improve the students' collaboration by using student-centered principle which is more effective and efficient.

Table 5. The Results of LSD Test on the Concept Understanding of the Students of Senior High School 1 Kairatu

\begin{tabular}{|c|c|c|c|c|}
\hline Class & X Concept Understanding & Y Concept Understanding & Difference & LSD Notation \\
\hline Control_Conventional Strategy & 22.79412 & 80.69853 & 57.9 & $\mathrm{a}$ \\
\hline
\end{tabular}

The influence of project-based learning strategies on the metacognitive skills ... (Dominggus Rumahlatu) 
The difference in the concept understanding between the students taught by using the project-based strategies and those taught by using conventional learning strategy is because the students in the project based learning strategy experienced a series of stages of doing a project. The implementation of the project consists of some stages, namely planning, investigation, presentation of results / products, and evaluation. In line with this, Han and Bhattacharya [23] state that the project-based learning consists of three stages, namely planning, creation, and process. Furthermore, Colley [24] reveals that the project-based learning includes the stages of identifying and determining a project, seeking information, planing the project, working on the project, reporting the results of the project, and evaluating the project that has been carried out.

In the planning process, the teachers direct the students to develop questions about biodiversity issues which are typical of Maluku, Indonesia. After that, the students are guided to prepare a design of investigation procedures for problem solving. Project-based learning is a strategy to encourage students to do research based on questions or problems [25]. The following stage is implementing the project through the investigation procedure to investigate the diversity level of genes, species and ecosystems which are typical of Maluku. Through this investigation procedure, the students are significantly trained to develop a concept for themselves.

The research by Ergul and Kargin [26] showed that very few students forgot their experiences during the process of project-based learning, because students could understand the concepts and were able to make a presentation of it. The next stage to develop the students' concept gaining is the presentation stage of the results of the project in the form of posters or leaflets of biodiversity. Movahedzadeh et al [27] explains that open discussion gives a contribution toward the students who have better understanding to share with other students. Through this scientific sharing, the students also explain their understanding and the findings of their projec. They even can tell about their confusion they encountered during the implementation of the project. In line with this, the research by Thompson et al [28] reveals that students develop the level of their concept understanding, problem solving and communication skills better, so that it helps them both in the academic world and in the future. The use of project-based learning strategy can improve the students' concept understanding of biodiversity better than the conventional strategy can.

A good metacognitive skill and good concept understanding will certainly have a contribution toward the students' retention. The effect of learning strategy on students' retention can be seen in Table 6 below.

Table 6. The Results of ANCOVA Test on the Retention of the Students of Senior High School 1 Kairatu

\begin{tabular}{llllll}
\hline Source & Type III Sum of Squares & df & Mean Square & F & Sig. \\
\hline Corrected Model & $1586.500^{\mathrm{a}}$ & 2 & 793.250 & 244.027 & .000 \\
Intercept & 126.857 & 1 & 126.857 & 39.025 & .000 \\
post_test & 730.472 & 1 & 730.472 & 224.715 & .000 \\
Strategy & 54.211 & 1 & 54.211 & 16.677 & .000 \\
Error & 120.275 & 37 & 3.251 & & \\
Total & 275113.000 & 40 & & & \\
Corrected Total & 1706.775 & 39 & & & \\
\hline
\end{tabular}

The results of ANCOVA Table 6 show that learning strategy variable makes a difference on the retention of the students Senior High School 1 Kairatu $(\mathrm{p}<0.05)$. This shows that learning strategy has an effect on the students' retention. Having been found that learning strategy has an effect on the students' retention, the LSD test is performed. The post hoc LSD test was performed to know the significant difference in the students' retention between the project based learning strategy and the conventional learning strategy. The results of the LSD test are presented in Table 7.

Table 7. The Results of the Post Hoc LSD Test on the Retention of the Students of Senior High School 1

\begin{tabular}{ccccc}
\hline Kairatu & & \\
\hline Class & X Retention & Y Retention & Difference & LSD Notation \\
\hline Control_Conventional Strategy & 75.3 & 77.3 & 2 & a \\
Experiment_Project based learning Strategy & 84.09 & 87 & 2.91 & b \\
\hline
\end{tabular}

The project based learning strategy has a greater potential in improving the students' retention than does the conventional learning strategy with a score difference between pretest and post-test as much as 0.91 Table 7. Research shows that whenthe students who learn by using project-based learning strategy have high metacognitive skills, they will also have a good concept gaining and retention. Similarly, Bahri [29] found 
that the use of appropriate learning strategies could empower the students' metacognitive skills, so that it could increase the students' cognitive retention. The research by Listiana et al [20] also shows that metacognitive skills are consistent and have a correlation with the improvement of the students'cognitive ability. Retention is an ability of memory to store information within a specified period. In this case is the students' retention ability of the biodiversity material. Anderson and Krathwohl [30] explain that retention is the ability to remember learning material until a certain period of time. The students' activity during the project-based learning strategy supports the students' retention ability. During the process of collecting information and doing investigation, the students discover concepts and experience real and meaningful learning. Gaines [31] states that one of the factors that affect student retention is meaningful learning, because when the learning material is meaningful, the students will understand it more easily.

Through this research, the students are invited to do a project on biodiversity which is typical of Maluku. In this case, the students will study the conditions and living things around them, so that it will become a meaningful experience for them. The research by deWinstanley and Bjork [32] reported that the students would remember the information they discover by themselves better than that they read. Retention is also associated with the student's ability to store information in long-term memory. The information which is obtained from doing a project and meaningful learning will certainly be stored in long term memory. This can increase students' retention better than the conventional learning strategy. Furthermore, Finley et al. [33] states that the students constructing knowledge by themselves will have an effect in their involvement in learning, encoding information, so that the information stored in long term memory can be quickly retrieved.

\section{CONCLUSION}

Based on the results of this research, it can be concluded that the implementation of project based learning strategy can improve metacognitive skills, concept gaining, and retention on biodiversity learning material of the students of Senior High School 1 Kairatu. This is proven with the differences in the notation which indicate that project-based learning strategy can improve metacognitive skills, concept, and retention more significantly compared to the conventional learning strategy done by the teacher.

\section{ACKNOWLEDGEMENTS}

The author would like to thank the Biology teacher of Senoir High School 1 Kairatu, West Seram District of, Maluku, who has given an assistance in the data collection. The author also thanks the Faculty of Teacher Training and Education Sciene, Pattimura University that has funded this research through grant research of social, humanities and education fiscal year 2017 in accordance with Rector Decree No. 630/UN13/SK/2017, dated June 12, 2017.

\section{REFERENCES}

[1] M. Windschitl, "Cultivating 21st Century Skills in Science Learners: how systems of teacher preparation and professional development will have to evolve. national academies of science", Workshop on 21st Century Skills, University of Washington, pp. 5-6, Feb. 2009.

[2] S. Zubaidah, "21st century skills: skills taught through learning (In Bahasa)" Paper presented at National Colloquium on Education with Themes: 21st Century MIPA Learning Strategic Issues, on 10 December 2016 at Biology Education Department STKIP Persada Khatulistiwa Sintang-West Kalimantan (In Bahasa).

[3] S. Zubaidah, N. M. Fuad, S. Mahanal and E. Suarsini, "Improving creative thinking skills of students through differentiated science inquiry integrated with mind map," Journal of Turkish Science Education, vol. 14, no. 4, pp. 77-91, 2017.

[4] Pacific Policy Research Center (PPRC), "21st century skills for students and teachers. Kamehameha Schools", Research \& Evaluation Division, pp. 1-25, Honolulu, 2010.

[5] O. S. Tan, Cognition, metacognition and problem based learning. in Tan, Oon Seng (ed). Enhancing Thingking Through Problem Based Learning Approaches, Thomson, Singapore, 2004.

[6] L. Greenstein, Assesing Skill 21st Century: A guide to evaluating mastery and authentic learning, U.S.A: Crowin A SAGE Company, 2012.

[7] R. N. S. R. Harun, "Metacognition in the 21st Century ESL teacher education programme," Proceedings of the 1st English Education International Conference (EEIC) in Conjuction with the 2nd Reciprocal Graduate Research Symposium (RGRS) of the Consortium of Asia-PAsific Education Universities (CAPEU) Betwwen Sultan Idris Education University and Syiah Kuala University, pp. 12-13, Nov. Banda Aceh, Indonesia, 2016.

[8] Yusnaeni and A. D. Corebima, "Empowering students' metacognitive skills on sscs learning model integrated with metacognitive strategy," The International Journal of Science and Humanities Invention, vol. 4, no. 5, pp. 3476-3481, 2017.

[9] L. Listiana, H. Susilo, H. Suwono and E. Suarsini, "Contributions from the GITTW (Group Investigation Combined Think Talk Write) Strategy," Proceeding of ICTTE FKIP UNS, vo. 1, no. 1, pp. 411-418, 2016. 
[10] J. W. Thomas, A review of research on project based learning, California: The Autodesk Foundation, 2000.

[11] S. Bell, "Project-based learning for the 21st century: Skills for the future," Clearing House: Journal of Educational Strategies, vol. 83, no. 2, pp. 39-43, 2010.

[12] I. Ilter, "A Study on the efficacy of project based learning approach n social studies education: Conceptual achievement and academic motivation," Journal Educational Research and Reviews, vol. 9, no. 15, pp. 487-497, 2014.

[13] Y. Sele, A. D. Corebima, and S. E. Indriwati, "The analysis of the teaching habit effect based on conventional learning in empowering metacognitive skills and critical thinking skills of senior high school students in Malang, Indonesia," International Journal of Academic Research and Development, vol. 1, no. 5, pp. 64-69, 2016.

[14] H. Setiawati and A. D. Corebima, "Empowering critical thinking skills of the students having different academic ability in biology learning of senior high school through PQ4R-TPS strategy," International Journal of Social Sciences and Humanities Invention, vol. 4, no. 5, pp. 3521-3526, 2017.

[15] A. G. C. Wicaksono and A. D. Corebima, "The correlation between students' metacognitive skills and retention at the implementation of reciprocal teaching learning strategu integrated with jigsaw in class X Senior High School 7 Malang," Jurnal BIOMA, vol. 4, no. 1, pp. 58-68, 2015.

[16] A. D. Corebima, "Metacognitive skill measurement integrated in achievement test," Paper presented at Seminar ketiga CosMed, Penang, Malaysia, 2019, [Online] Available: http://ftp.recsam.edu.my/cosmed/cosmed09/Abstracts FullPapers2009/Abstract/Science\%20Paralle1\%20PDF/Full\%20Paper/01.pdf. [Accesed on 10 Jan 2018.]

[17] H. Suwono, "Project based learning to improve learning outcomes for limnology at the Department of Biology," Journal Of Science Education, vol. 17, no. 5, pp. 368-377, 2011.

[18] D. Hellström, F. Nilsson and A. Olsson, Group assessment challenges in project-based learning - Perceptions from students in higher engineering courses. Paper presented at 2:a Utvecklingskonferensen för Sveriges ingenjörsutbildningar, LTH 2-3 Dec. Lund, Sweden. 2009.

[19] M. Palennari, "Exploring the correlation between metacognition and cognitive retention of students using some biology teaching strategies," Journal of Baltic Science Education, vol. 15, no. 5, pp. 617-626, 2016.

[20] L. Listiana, H. Susilo, H. Suwono and E. Suarsini, "Empowering student's metacognitive skills through new teaching strategy (group investigation integrated with think talk write) in Biology Classroom," Journal of Baltic Science Education, vol. 15, no. 3, pp. 391-400, 2016.

[21] Suparti, "Project based learning guided lesson study improve the achievement of learning outcomes on seminar accounting education course at the department of accounting," Journal of Research and Methods in Education, vol. 5, no.3, pp. 05-11, 2015.

[22] T. Koparan and B. Guven, "The effect of project based learning on the statistical literacy levels of student 8th grade," Journal of Education Research, vol. 3, no. 3, pp. 145-157, 2014.

[23] S. Han and K. Bhattacharya, "Constructionism, learning by design, and project-based learning," in M. Orey (Ed.), Emergingperspectives on learning, teaching, and technology, 2001. [Online] Available: coe.uga, http://www.coe.uga.edu/epltt/LearningbyDesign.htm. [Accesed on 10 Jan 2018].

[24] K. Colley, "Project based science instruction: A primer," Journal The Science Teacher, vol. 75, no. 8, pp. 23-28, 2008.

[25] P. C. Blumenfeld, E. Soloway, R. W. Marx, J. S. Krajcik, M. Guzdial and A. Palincsar, "Motivating project-based learning: sustaining the doing, supporting the learning," Journal Educational Psychologist, vol. 26, no. 3 and 4, pp. 369-398, 1991.

[26] N. R. Ergül and E. K. Kargin, "The effect of project based learning on students' science success," Procedia Social and Behavioral Sciences, vol. 136, pp. 537-541, 2014.

[27] F. Movahedzadeh, R. Patwell, J. E. Rieker \& T. Gonzales, "Project based learning to promote effective learning in Biotechnology Courses," Education Research Internasional, pp. 1-8, 2012.

[28] K. J. Thompson and J. Beak, "The Leadership Book: Enhancing the theory-practice connection through projectbased learning," Journal of Management Education, vol. 31, no. 2, pp. 278-291, 2007.

[29] A. Bahri, "Exploring the correlation between metacognitive skills and retention of student in different learning strategies in Biology Classroom," Proceeding of ICMSTEA, pp. 156-161, 2016.

[30] O. W. Anderson and D. R. Krathwohl, A taxonomy for learning, teaching, and assesing. Addision Wesley Longman, Inc, New York, 2001.

[31] M. Gaines, M. "What factors effect retention in the calssroom? Wakefield High School Arlington County (VA) Public Schools," pp. 1-7, 2001. [Online], [Available] (http://www.ulster.ac.uk/star/resources//wht_fctrs_effct_ retention.pdf), Accesed on 10 January 2018.

[32] P. A. deWisntley and E. L. Bjork, "Processing strategies and the generation effect: implication for making a better reader," Journal of Memory and Cognition, vol. 32, no. 6, pp. 945-955, 2004.

[33] J. R. Finley, J. G. Tullis and A. S. Benjamin., "Metacognitive control of learning and remembering," New Science of Learning, pp. 109-131, 2010. 